\title{
STRONG CONVERGENCE THEOREMS OF STRONGLY RELATIVELY NONEXPANSIVE SEMI-GROUP IN BANACH SPACES
}

\author{
ZHAOLI MA AND LIN WANG
}

Abstract. In this paper, we prove some strong convergence approximation theorems of strongly relatively nonexpansive semi-group in the framework of Banach spaces. Using the concept of duality theorems, we obtain analogue results for strongly generalized nonexpansive semi-group and for semi-group of firmly generalized nonexpansive type. The results presented in this paper improve and extend some corresponding results announced by some authors.

Mathematics subject classification (2010): 47H09, 47J25.

Keywords and phrases: Strongly relatively nonexpansive semi-group, relatively nonexpansive semigroup, relatively nonexpansive mappings, strongly generalized nonexpansive semi-group, generalized projection.

\section{REFERENCES}

[1] YA. I. ALBER, Metric and generalized projection operators in Banach spaces: properties and applications, in: A. G. Kartsatos(Ed.), Theory and Applications of Nonlinear Operators of Accretive and Monotonic Type, Marcel Dekker, New York, 1996, pp. 15-50.

[2] YA. I. ALBER, S. REICH, An iterative method for solving a class of nonlinear operator equations in Banach spaces, Panamer. Math. J. 4, (2) 1994, 39-54.

[3] R. E. BRUCK, S. REICH, Nonexpansive projections and resolvents of accretive operators in Banach spaces, Houston J. Math. 3, (1997) 459-470.

[4] I. Cioranescu, Geometry of Banach Spaces, Duality Mappings and Nonlinear Problems, Kluwer Academic Publishers, Dordrecht, 1990.

[5] Y. CENSOR, S. REICH, Iterations of paracontractions and firmly nonexpansive operators with applications to feasibility and optimization, Optimization 37, (1996)323-339.

[6] C. E. Chidume, E. U. Ofoedu, H. ZeGEYe, Strong and weak convergence theorems for asymptotically nonexpansive mappings, J. Math. Anal. Appl., 280, (2003), 364-374.

[7] S.-S. Chang, L. YAng, J. A. LiU, Strong convergence theorem for nonexpansive semi-groups in Banach spaces, Appl. Math. Mech., 28, (2007) 1287-1297.

[8] S.-S. Chang, H. W. Joseph Lee, C. K. Chan, Convergence theorem of common fixed point for asymptotically nonexpansive semigroups in Banach spaces, Appl. Math. Comput., 212, (2009) 60-65.

[9] S. S. Chang, C. K. Chan, H. W. Joseph LeE, Modified Block iterative algorithm for quasi- $\phi$ asymptotically nonexpansive mappings and equilibrium problem in Banach spaces, Applied Math. Comput., (2011), 7520-7530.

[10] S. S. Chang, L. WANG, Y. K. TANG, Y. H. ZhaO, B. WANG, Strong convergence theorems for quasi- $\phi$-asymptotically nonexpansive semi-groups in Banach spaces, Fixed Point Theory and Applications 2012, 2012:15, doi:10.1186/1687-1812-2012-15.

[11] T. HONDA, T. IBARAKI, W. TAKAHASHI, Duality theorems and convergence theorems for nonlinear mappings in Banach spaces and applications, Int. J. Math. Stat., 6, (2010) 46-64.

[12] T. IBARAKI, W. TAKAHASHI, A new projection and convergence theorems for projections in Banach spaces, J. Approx. Theory, 149, (2007)1-14.

[13] S. KAMIMURA, W. TAKAHASHI, Strong convergence of a proximal-type algorithm in Banach space, SIAM J. O ptim. 13, (2002), 938-945. 
[14] F. KOHSAKA, W. TAKAHASHI, Existence and approximation of fixed points of firmly nonexpansivetype mappings in Banach spaces, SIAM J. Optim. 19, (2008) 824-835.

[15] F. KOHSAKA, W. TAKAHASHI, Approximating common fixed points of countable families of strongly nonexpansive mappings, Nolinear Stud., 14, (2007) 219-234.

[16] F. KOHSAKA, W. TAKAHASHI, Generalized nonexpansive retractions and a proximal-type algorithm in Banach spaces, J. Nonlinear Convex Anal., 8, (2007) 197-209.

[17] S. Matsushita, W. TAKAhASHI, Weak and strong convergence theorems for relatively nonexpansive mappings in Banach space, Fixed Point Theory Appl. 2004, (2004) 37-47.

[18] S. MatsushitA, W. TAKAHASHI, A strong convergence theorem for relatively nonexpansive mappings in Banach space, J. Approx. Theory 134, (2005) 257-266.

[19] P. E. MAINGE, Strong convergence of projected subgradient methods for nonsmooth and nonstrictly convex minimization, Set-Valued Anal. 16, (2008) 899-912.

[20] W. Nilsrakoo, S. Saejung, Strong convergence to common fixed points of countable relatively quasi-nonexpansive mappings, Fixed Point Theory Appl., 2008 (2008) Article ID 312454, 19 pages.

[21] W. NILSRAKOO, Halpern-type iterations for strongly relatively nonexpansive mappings in Banach spaces, Computers and Mathmatics with Applications 62, (2011) 4656-4666.

[22] W. Nilsrakoo, S. S Aejung, Strong convergence theorems by Halpern-Mann iterations for relatively nonexpansive mappings in Banach spaces, Applied Mathematics and computation 217, (2011) $6577-6586$.

[23] J. W. PENG AND J.-C. YAO, Two extragradient method for generalized mixed equilibrium problems, nonexpansive mappings and monotone mappings, Computers and Mathematics with Applications, 58, (2009), 1287-1301.

[24] S. REICH, A weak convergence theorem for the alternating methor with Bregman distance, in: Theory and Applications of Nonlinear Operators of Accretive and Monotonic Type, in: Lecture Notes in Pure and Appl. Math., 178, Dekker, New York, 1996, pp. 313-318.

[25] Y. F. SU, H. K. XU, X. ZHANG, Strong convergence theorems for two countable families of weak relatively nonexpansive mappings and applications, Nonlinear Anal., 73, (2010), 3890-3906.

[26] T. SUZUKI, On strong convergence to common fixed points of nonexpansive semigroups in Hilbert spaces, Proc. Am. Math. Soc. 131, (2003) 2133-2136.

[27] S. SAEJUnG, Halpern's iteration in Banach spaces, Nonlinear Anal., 73, (2010) 3431-3439.

[28] W. TAKahashi, Nonlinear Functional Analysis, Yokohama Publishers, Yokohama, 2000.

[29] K. K. TAN, H. K. XU, Approximating fixed points of nonexpansive mappings by the Ishikawa iteration process, J. Math. Anal. Appl., 178, (1993) 301-308.

[30] H. K. XU, Another control condition in an iterative method for nonexpansive mappings, Bull. Austral. Math. Soc., 65, (2002) 109-113. 